\title{
Corporate Governance: An Overview. From Creation of Value for Shareholders by the Board to the Duality Role of Its Chairperson
}

\author{
Michel Sayumwe ${ }^{1}$ \\ ${ }^{1}$ University of Quebec at Montreal, Canada \\ Correspondence: Michel Sayumwe, University of Quebec at Montreal, Canada \\ Received: February 14, 2019 \\ Accepted: March 6, 2019 \\ Online Published: March 7, 2019 \\ doi:10.5430/jbar.v8n1p40 \\ URL: https://doi.org/10.5430/jbar.v8n1p40
}

\begin{abstract}
In this paper, we discuss the evolution of the literature on corporate governance based on many theoretical perspectives, including agency theory, stakeholder theory, theory of resource dependence and stewardship theory.

Keywords: corporate governance, creation of value, board of directors, financial reporting, agency theory, stakeholder theory

\section{Introduction}

The literature on corporate governance is very dense. The problem of corporate governance tradition stems from the separation that generally exists between ownership and management.

From the scientific point of view, several stakeholders are interested in the way in which power is exercised by the corporate management of companies. For us, it is essential to survey the governance literature to examine the different mechanisms proposed by different scientific theories such as agency theory (Jensen and Meckling, 1976), stakeholder theory (Freeman and Reed, 1983; Freeman, 1984), the theory of resource dependence (Pfeffer and Salancik, 1978) and stewardship theory (Donaldson and Davis 1989; Donaldson 1990).

By mobilizing different scientific theories that can explain the management behavior, this review of the governance literature addresses issues as diverse as value creation for shareholders (section 2), the functioning of the board of directors (sections 3 to 6) including its size, the independence of its members and the frequency of meetings. In sections 7 to 9, this article discusses the Audit Committee role, the compensation of directors and the quality of financial information. We conclude in sections 10 and 11 by discussing the type of ownership and the presence of duality in the role of the CEO and the Chairman of the Board.
\end{abstract}

\section{Creation of Value for Shareholders}

Stakeholders must have certain relevant capabilities to be able to create value, namely, to be employable, autonomous, innovative, entrepreneurial, responsive and socially integrated (Garriga, 2014). Vidal et al (2014) attempts to study the factors influencing the value creation of Brazilian companies. They suggest that a better work environment, customer growth, local development, reputation, and stakeholder dialogue appear to be the driving forces behind business value creation in Brazil stakeholders.

Value creation, according to Pandya (2016), is an essential element in evaluating the efficiency and effectiveness of companies around the world. Singh (2014) suggests that shareholder value creation is the profit that shareholders receive through better management linked to a series of provisions such as the adoption of strategic cost management techniques, branding, the efficient use of resources and the internal structure of the company. In a study of the Indian market, he seeks to test how intangible assets would lead to value creation and how depreciation practices would affect profitability and value creation. He notes that the different methods used in industries, given their usefulness and effectiveness, directly affect the profits of firms. An effective management system for managing intangible assets, he says, can improve earning capacity for value creation for competing companies.

In the same vein, Atiyet (2012) seeks to determine the most important factors for creating value for corporate shareholders and the impact of capital structure of value creation for shareholders. The results of this study suggest that this depends on the measure taken of either the economic value added (EVA) or the market value added (MVA). With the EVA, French companies are prioritizing how they should finance their activities for value creation. First, they are self-financing in order to avoid agency fees following the demand for external financing, then by the debt and finally 
by the issue of shares. Nevertheless, with the MVA measure, self-financing is the structure to create shareholder value but not debt. According to Fernandez (2001) cited in Atiyet (2012), a company creates value for shareholders when it exceeds their expectations in terms of return.

The increase in market capitalization, according to Singh and Anand (2013), leads to the creation of higher intangible assets which could improve the value of shareholders' shares over the long term. This takes into account external factors such as the State's economic situation, the political situation and the government's policy towards the industry in general. Indeed, the increase in this value also depends on internal factors such as dividend policy, organizational structure, employee competence, and so on. They argue that, with all of these changes, investors will be encouraged to acquire shares at higher rates and as a result will create intangible assets of the company.

Hall (2012) seeks to determine statistically how value drivers in a manufacturing company contribute to value creation. He concludes that if Management is able to identify the people responsible for these drivers, value creation for shareholders can be optimized in value by its active operational decisions.

\section{Financial Reporting, Board of Directors and Market Performance}

Firms that maintain good governance help to reduce agency problems with financing, and have a greater reaction in short-term market advertising. This also influences the long-term market outcomes of their parent companies (Chahine \& Zeidan, 2014). In a study of the existence of corporate governance practices across European societies, Müller \& al. (2014) find that the board's characteristics have a strong influence on corporate performance and confirm the existence of best governance practices that are exemplary compared to other countries. Mirza \& Javed (2013) share this view. They suggest that companies with a well-governed ownership structure, good capital structure, adequate risk management and appropriate controls tend to be more profitable for shareholders. In addition, increasing the value of investor wealth should be achieved by improving governance practices.

According to Eberhart (2012), the choice of a shareholder-driven governance system can improve corporate value compared to the traditional system of statutory auditors in Japan. The results show that companies adopting such a governance system send clear signals resulting from transparency and oversight of directors. This leads to a reduction in agency costs and an increase in the value of the company. Rashid and Islam (2013) analyzed the role of governance instruments on the value of a business. They suggest that a strong regulatory regime can enhance the value of a business by protecting the rights of minority shareholders over the majority shareholders who expropriate them in the marketplace.

Analyzing the impact of corporate governance on the determinants of performance in Pakistan's banking sector, Inam \& Mukhtar (2014) find that banks with good governance perform better than other banks that. They conclude that good governance presents instructions that can increase selected indicators such as interest income, return on equity, and net income of banks. It has a favorable effect on the financial disclosure of a bank. On the other hands, Kara \& al (2015) share the same direction, studying the impact of corporate governance on the financial performance of companies listed on the XKURY index in Turkey. They suggest that companies that have adopted good governance, given the implementation of positive changes for better management, appear to be more reliable for creditors. In addition, there is a causal relationship between the corporate governance rating score and the Tobin $\mathrm{Q}$ value, as well as the leverage ratio.

Bozec \& Dia (2015) examine the link between corporate governance practices and performance while considering the proximity of shareholders and managers. The study suggests that the concentration of ownership and ownership of key strategic positions by shareholders has no effect on the relationship between governance and performance. It is argued that improving governance best practices while prioritizing an independent board of directors that opts for transparency and control, could increase the value of the company and allow shareholders / managers to work in the best interests of the company. According to Mohd-Sulaiman (2013), the independence and competence of directors are two criteria that contribute to improving the management of the company and preventing the failure of governance. They are effective depending on how they are exercised. Ben (2014), for his part, believes that Indian companies with large disclosures have higher valuations by investors. This would make them more transparent and lead to improved governance mechanisms.

Lattemann (2014) analyzes the convergence and adaptation of corporate governance practices in emerging markets, particularly in the BRIC countries (Brazil, Russia, India and China). It suggests that these countries adopt good corporate governance compared to that used in developed countries and that companies align themselves with foreign and international governance practices voluntarily taking into account their institutional and environmental context. He argues that large BRIC companies are following best practices and appear to be superior to the internal practices of 
companies in these countries.

\section{Board of Directors Size}

The size of the board contributes to its effectiveness in its functions to maximize the value of the company and would influence the performance of the company (Siahaan, 2013). In an emerging Jordanian study, there was a positive and significant relationship between a large board and performance measured by asset returns and return on equity (Alabdullah, 2016). In the Indian context, Bhatt and Bhattacharya (2015) suggest that a large board improves the financial performance of the company because it contributes favorably through its expertise and also makes it difficult for a CEO of a family business with power control, to influence this type of advice.

For their part, Malik \& al. (2014) find a positive relationship between board size and performance in the Pakistan context. They suggest that a large board improves the performance of banks in Pakistan.

In a developing market, a large board of directors is preferable in companies because directors participate in constructive activities that enhance the value of these companies (Rashid \& Islam, 2011). In their article, Aman \& Nguyen (2012) analyze the structure of boards of directors in companies in Japan. The results suggest that the size of the board depends on the size and complexity of the business. Indeed, the size of the board tends to increase with the needs of the company and decreases when the coordination costs become arbitrary or abusive. It is in this context that Wang \& al. (2013) suggest that companies with complex structures need a large board and this has a positive influence on performance, in that the contribution of these board members is more important in their advisory role with respect to problems, such as communication and decision-making that may occur. On the other hand, they find an inverse relationship between board size and performance for companies with simple structures. However, Godard (2002) suggests that the size of the board of directors depends on that of the company. Indeed, the author estimates that it is smaller in family businesses since the number of outside directors is limited by the control of family shareholders. In addition, it has been found that in diversified companies, a board with many members facilitates the exchange of knowledge between various qualified personalities whose experience and skills correspond to the corporate strategy.

In the Malaysian economic environment, Ghasemi \& Ab Razak (2016) studied the effect of the size of the board and executive directors on corporate performance. The authors suggest that boards with many frames would be more preferred in the Malaysian market. The results show a positive effect between the size of the board and the performance of the company because big boards are given many opportunities to have more collective information and increase the commercial links. They suggest that the presence of experts improves the decision-making process.

While for some authors a board with many members seems to contribute to the smooth running of the company, according to others, the results are inconclusive. Indeed, Sarpal \& Singh (2013) suggest that size has no significant influence on company performance and may vary depending on the type of shareholding structures across a country. They argue that, in the Indian context, shareholders are family members belonging to concentrate business structures and having control over the boards in the decision-making process. This suggests that the contribution of outside directors appears to be attenuated by their presence on the board. In addition, size can not affect performance because of the influence of family members in counseling. Kumar \& Singh (2013) find that the size of the board has a negative influence on the performance of Indian companies. Given the complexity of the decision-making process, a large board does not promote better decision-making because of a communication and coordination problem.

\section{Independence of the Board}

The independence of directors is considered to be one of the features of this governance mechanism that several authors are studying after the recent financial crises of 2008. In terms of corporate governance, several countries have made changes to the regulation of corporate governance, in particular by strengthening the board's structure with the presence of independent directors. Thus, Wu and Li (2015), in the chinese context, uggested that the presence of such directors not only improves governance, especially in terms of supervision and control, but also the performance of companies given a change in corporate governance regulations. On the other hand, Rahman \& al. (2015) note, after the introduction of the new recommendations on governance regulation in Malaysia, that there is no relationship between the presence of independent directors and the voluntary application of new regulations. Sun \& al.'s article (2014) agrees and suggests that the interaction of board independence and growth opportunities after Sarbanes and Oxley (SOX) on performance is negative. However, there appears to be a positive relationship between the investment opportunity and the company's performance during the post-SOX period.

The presence of independent directors on boards of directors leads to an improvement in the scope and quality of corporate governance (Nuhoglu \& Erdogan, 2017). Indeed, Gupta (2013) suggests that improving governance through these professionals leads to increased investment and growth in industries. 
A change in the general management of the company may allow the new CEO to make opportunistic decisions to the detriment of shareholders given the confidence he has had in making the business more profitable. However, the new CEO can make decisions in this strategic shift by prioritizing his own interests. In this logic, Li \& Xu (2014) suggest that independent directors can control this aggressive behavior of the new CEO, in order to protect the interests of shareholders. In a study conducted on the Chinese market, $\mathrm{Wu}$ and $\mathrm{Li}$ (2014) concluded that the presence of these administrators strengthens control, which would reduce the likelihood of breach of governance principles.

Board independence helps to strengthen financial transparency and requires managers, given their discretionary behavior, to align with the principle of voluntary disclosure in family businesses. Chakroun's article (2013) analyzes the relationship between control exercised in a family business and the extent of the voluntary disclosure of annual reports through the independence of the board of directors in the Tunisian context. The author notes an increase in the scope of voluntary disclosure following the promulgation of the law on strengthening the security of financial relations. Goh \& Rasli (2014), on the other hand, believe that in Malaysian family businesses, the independence of the board of directors is not an effective oversight mechanism but is a tool to strengthen the control of minority shareholders in these companies. .

Independent directors may contribute to the financial performance of the company at a certain level of representativeness in the Roman context according to Vintilă \& Gherghina (2013), but when they exceed this threshold, a negative relationship has been noted. They believe that not all directors are effective in their oversight role.

Finally, Bhatt \& Bhattacharya (2015) concluded that the presence of independent directors does not improve the financial performance of companies in India as these professionals do not have sufficient qualifications to perform their duties effectively. They argue that firms would need qualified independent directors to help them solve problems and properly perform supervisory and control roles, which would improve the corporate governance.

\section{Frequency of the Meetings}

The frequency of board meetings has a positive impact on the financial performance of the company (Shittu \& al., 2016). In a study conducted in Australia, Hoque \& al. (2013) have complemented this view. The article concludes that there is a positive and significant relationship between the frequency of meetings and the financial performance measured by asset returns and return on equity ratios.

A large number of meetings could allow the board to have the necessary information on the different operations and the possibility of increasing the visibility of companies (Rodriguez-Fernandez \& al., 2014). These reveal that the frequency of board meetings has an influence on the financial performance of companies in Spain. In a study conducted in Pakistan, Irshad \& al. (2015) find a significant positive impact on the frequency of meetings on the company's performance. According to them, businesses that belong to closed and family groups hold meetings at a high frequency. This promotes exchanges between board members, and implies better coordination in decision-making.

Chen (2012) examines the effects of board characteristics, including the frequency of board meetings on R \& D investments using a dataset of publicly traded electronics companies in Taiwan. The results of this study suggest that the effect of the frequency of board meetings on R \& D investments is positive, but not significant. Vincent \& al (2010) share the same point. They find that when the frequency of meetings is high, this gives directors the opportunity to devote more time and effort to strengthening the strategy and running the business by bringing their experience, knowledge and judgment. Nevertheless, it was found that in Indian IT Sector, the frequency of board meetings has no impact on the performance of the company, but the attendance of directors at meetings seems to have a significant influence on the performance of the board (Bhatt \& Bhattacharya, 2015).

García-Ramos \& García-Olalla (2011) find that a high frequency of board meetings in family businesses in Europe improves financial performance. In Spain, on the other hand, an increasing number of meetings do not contribute to improving the situation of companies (Rodriguez-Fernandez et al., 2014).

In France, Barros \& al. (2013) find that voluntary disclosure increases with the frequency of board meetings. Nevertheless, they note a decrease of this one with the frequency of the meetings of the audit committee. In a study conducted on the determinants of the frequency of audit committee meetings listed in Chinese companies, Yin $\&$ al. (2012) suggest that the frequency of audit committee meetings is negatively associated with the proportion of shares held by a majority shareholder and that the number of audit committee meetings is lower in public companies than in private ones. It seems that, in the Chinese context, the guidelines on corporate governance are less stringent and companies have discretion to set the number of meetings of the audit committee. 


\section{Audit Committee}

The characteristics of the audit committee affect the quality of financial reporting (Kibiya \& al., 2016). The mixed nature of this committee, especially with the presence of an accounting expert, guarantees a better quality of financial reports. One cannot necessarily have the same expectation with the mere presence of experts in finance or supervision of an audit committee (Leong \& al., 2015). In a study conducted on the Chinese market, Yin \& al. (2012) found a positive association between the characteristics and the number of meetings of the audit committee.

Independence and diligence are critical to the activities of an audit committee (Adelopo et al., 2012). Strengthening the former and associating it with the competence promotes the integrity of the financial statements. As for diligence, it helps reduce external audit costs (Dellaportas \& al., 2012). This independence may be compromised due to the political link between audit committee members (Lin \& al., 2015). This is what the authors found through a study in the Chinese context where government representatives are appointed as independent members of the audit committees. The size of an audit committee, the independence of its members and the duality of its chairman have an impact on its operations. While the first two provide an improvement, the third makes it less effective (Abdel-Meguid et al., 2014).

In corporate governance, placing too much emphasis on the supervisory role affects the effectiveness of boards of directors (Brennan \& Kirwan, 2015). The approach proposed by these authors, advocates a rather holistic view of the role of the audit committee. According to this point of view, it is better for the audit committee to play the traditional role of oversight. It should be recognized, however, that in practice, the effectiveness of corporate governance is fluid, contextual and dependent on the skills, initiative and adaptation of practitioners.

The combination of financial expertise with practical experience in financial statements preparation or industry experience enhances the ability of audit committees to monitor the quality of financial reporting (Sun \& al. 2012). In another context, the effectiveness of the audit committee can help to improve the quality of financial reporting in emerging countries. It can facilitate the management of submission deadlines for the stock market (Ika \& Ghazali, 2012).

The characteristics of the audit committee in terms of independence, size, expertise of members and number of meetings can help prevent earnings management (Nelson \& Devi, 2013). This increases with the use of stock options in the compensation packages of the Audit Committee (Lynch \& Williams, 2012) and with the granting of additional mandates to members of the Audit Committee (Sun \& al., 2014). Balance in audit committees is of paramount importance to achieve efficiency. The characteristics related to independence and expertise do not allow this effectiveness. Financial expertise is important but not enough. In addition, the chair of the board must be able to establish and maintain a functional group dynamic among the various skills that make up the committee. He must be able to manage the conflicts that will inevitably be generated by the diversity that characterizes the group (Martinov-Bennie \& al., 2015).

\section{Compensation of Directors}

The percentage of incentive rewards in the executive director's total compensation are higher when the latter occupies the position of the chairman of the board of directors (Cheffou, 2014).

In the presence of a fixed component compensation structure and a lack of effective control mechanisms to mitigate management compensation, director compensation can be a factor in extracting shareholder wealth. In the face of such a situation, directors' excessive remuneration negatively affects the company's earnings, the ability to meet shareholder dividends and the undistributed earnings to finance maintenance and growth (Merino \& al., 2013). This issue of excessive remuneration tends to be greater in the presence of independent directors on the board of directors or the remuneration committee (Khenissi, 2014). The study results of Pucheta-Martínez \& Narro-Forés (2014) have shown that an increase in the number of independent, owner and management members does not change the variation in the average remuneration of directors. Indeed, director compensation is based on the percentage of independent directors and the size of the board (Lee \& Isa, 2015). The link is positive with the first and negative with the second. According to these authors, there is no link between the duality and the remuneration of the directors.

In the absence of compensation committees, compensation policies, lack of performance-based compensation, and lack of disclosure of executive compensation information, there is no guarantee that compensation policies will be aligned best practices or that they will be allocated with respect to the protection of shareholders' interests (Braje \& Subic, 2016). A causal relationship has been observed by Appiah \& Chizema (2015) between the failure of a company and the independence of the compensation committee. An effective compensation committee must properly perform its role of controlling director compensation. In the case of family businesses, in search of motivation for long-term success, family members combine power with control to streamline director compensation (Jaafar \& James, 2013). 
While director compensation increases the intrinsic value of the company, its growth does not imply a growth in performance (Aggarwal \& Ghosh, 2015). In South Africa, the growing wage gap has significant socio-economic consequences. There is no match between the performance of companies and the remuneration of their executives (Viviers, 2015). These results are not unanimous in the literature.

\section{Financial Information and Corporate Governance}

Ensuring the quality of financial information is one of the most important roles that corporate governance can play (Honu \& Gajevszky, 2014). This relates to the tasks and responsibilities of the sharing of responsibilities among directors (Higson, 2013). It is able to guarantee the quality of financial information and leads to transparency and reliability (Kumari \& Pattanayak, 2014). It can reduce or even eliminate the extent of earnings management and, to some extent, can be used to control agency problems among managers (Man \& Wong, 2013). The changes imposed by the stock exchanges and the US Congress in the Sarbanes-Oxley Act of 2002 have had a positive impact on internal governance (Baber \& al., 2012). A correlation of the components of the audit as a whole (internal audit, external audit and audit committees) must be beneficial for the company because it improves governance (Fülöp, 2013). The weakness of internal control in a company reflects its risks to the business environment (Agyei-Mensah, 2016).

In their study, Hashim \& al. (2014) found information retention at the level of Malaysian firms. These only disclose information related to their vision and philosophy, strategic planning and commercial competition. Voluntary disclosure of information beyond legal requirements allows companies in emerging markets to attract more investors and publicize their performance (Ismail \& El-Shaib, 2012). The study of these authors also revealed that the size of the boards of directors can help a better disclosure of the strategic information. According to Al-Najjar \& Abed (2014), the level of disclosure of information varies according to the size, performance, cross-listing and operating cash flow of the company. It is also related to the independence of the audit committee and the ownership structure. Asymmetric information negatively affects the quality of financial information. By reducing it and using governance mechanisms to promote the quality of accounting information, IFRS can significantly contribute to improving the quality of financial reporting (Kao, 2014). A company that complies with IFRS standards with good corporate governance practices for accountability and transparency is in a good position to provide quality financial information. Further, the authors find that there is no link between the quality of financial information produced by Malaysian firms because they are audited by international audit firms (Hla, \& Bin Md Isa, 2015).

A conclusion from a research by Honu \& Gajevszky (2014) suggests that the size and age of the company, as well as that of the audit committee, have a significant influence on the quality of financial reporting. In particular, there is a positive association between the age of the company and the quality of the financial reports.

\section{Type of Ownership}

The ownership concentration and the degree of control of the shareholders impacts the performance of the company differently. An increased concentration of ownership is positively related to return on equity and negatively to return on assets (Alipour \& al., 2013). A concentration of common shares held by three major shareholders from 7.3\% to $73 \%$ reduces the dividend yield on common and preferred shares. But a proportion of $73 \%$ to $95 \%$ concentration will imply an increase in the dividend payout ratio (Berezinets \& al., 2014). Conversely, Busta \& al. (2014); Hanafi \& al. (2013) find a positive relationship between the concentration of ownership and the profitability of total assets.

In a study led by Lee \& Lee (2014), it was found that a high concentration of managers and controlling shareholder participation has a significant negative effect on the company's performance. Contrary to these results, it was found that in the framework of the Tunisian economy, the ownership structure does not affect performance in the banking sector (Aymen, 2014). In the banking sector, a concentrated ownership structure can help improve risk-taking and profitability (Hanafi \& al., 2013). It allows banks to be better capitalized and more liquid (Chalermchatvichien \& al., 2014). This type of ownership is an important factor to consider in assessing a bank's performance (Ehsan \& Javid, 2015). Advocating that it is more important to know the effect of the type of ownership, the authors confirm the negative impact of State ownership on the bank's performance.

Concentrated ownership structure does not affect the performance of non-financial firms (Al-Saidi \& Al-Shammari, 2015). Hall \& Jörgensen (2012) suggest that the concentration of ownership of a single large block of shares has negative impacts on performance when minority shareholders are not sufficiently protected. In contrast, a concentration for a coalition of the top five shareholders is positively related to performance. Diversity of ownership type plays a major role in explaining the performance of innovation (Chen \& al., 2014). A concentrated structure can be useful in case of financial distress. This is because governments will be more likely to participate in a rescue strategy when the ownership structure is stable and concentrated (Deudon et al., 2015). 
When ownership in a corporation is widely dispersed, shareholders are less willing and able to monitor and discipline managers. Reduced dispersion can help improve governance (Brunzell \& Peltomäki, 2015).

\section{Duality in the role of the CEO and the Board Chairperson.}

The non-separation of CEO and chairperson positions poses a lot of challenges given the accepted governance practices in some countries. Rashid (2013) seeks to determine whether the duality of CEO reduces the cost of corporate agency in Bangladesh. He notes that the non-separation of the executive function does not reduce agency costs because it allows CEOs to have more authority, which would diminish the control and ability of directors to properly perform their oversight role. Based on the agency's theory, Abels \& Martelli (2013) echo this and suggest that duality would lead to an increase in the agency's costs because management would take care of its own interest to the detriment of the shareholders. Indeed, management holds a dominant power over the board of directors and would reduce the control power of the board by weakening the independence and transparency of the company. However, in family businesses, Liu \& al. (2012) argue that agency costs are reduced given the requirement of the relationship between shareholders and managers of these firms and will result in higher performance. In a study conducted in the Malaysian context, Goh \& Rasli (2014) find that owners of family businesses do not consider duality as a means to weaken the control of large non-dominant shareholders, but to safeguard family interests. Indeed, they would put in place a rigorous control in view of the negative effects recorded with respect to this structure, despite the benefits they enjoy from their connections and the lower agency costs related to their altruistic behavior.

Syriopoulos \& Tsatsaronis (2012) studied the impact of duality on the financial performance of shipping companies. The authors suggest that, taking into account the agency's theory, the separation of the functions of CEO and the board chairperson represents a good governance practice that takes into account shareholder interests and allows for better monitoring and control of the activities of the top management. This would imply an improvement in the company's performance. However, they also suggest, according to the stewardship theory, the fact that the non-separation of functions follows an identical chain of command, it facilitates the reduction of contradictory decision-making and would lead to an improvement of the company's performance.

Independent directors should effectively oversee the opportunistic behavior of a new CEO and this could lead to poor performance for the firm ( $\mathrm{Li} \& \mathrm{Xu}, 2014)$. Strengthening the effectiveness of independent directors in their view is essential and the company's oversight mechanisms need to be improved during the process of changing the new CEO in order to mitigate the risk of operating the company in their interests.

For its part, Lin (2012) finds that, in emerging countries, particularly in Taiwan, the positions of Chairman of the Board of Directors and the control of companies are the responsibility of the majority shareholders. Any change in the chairperson position would result in the loss of control rights for the board. He believes that the duality of the CEO is one of the essential means that would reduce the possibility of change of the board chairperson and allow shareholders to defend their interests, in particular the maintenance of their control rights. In this context, the author reveals that the agency problem does not exist between the managers and the shareholders, but rather between the majority shareholders and the minority shareholders.

\section{Limits of Our Study and Conclusion.}

Although our paper includes the relevant literature on corporate governance, it limits the analysis of the relationship between the management and the shareholders. Some issues may arise between dominant and non-controlling shareholders. This review was mainly based on developed economies, even if in the developing countries, companies face singular corporate governance issues. Future research may deal with theses matters. Nevertheless, this overview is inclusive and takes into account many theoretical perspectives, such the agency theory to the stakeholder theory.

\section{References}

Abels, P. B., \& Martelli, J. T. (2013). CEO duality: how many hats are too many? Corporate Governance: The international journal of business in society, 13(2), 135-147. https://doi.org/10.1108/14720701311316625

Abdel-Meguid, A., Samaha, K., \& Dahawy, K. (2014). Preliminary evidence on the relationship between corporate governance attributes and audit committee functionality in Egypt: beyond checking the box. Corporate Governance, 14(2), 197-210. https://doi.org/10.1108/CG-01-2011-0004

Adelopo, I., Jallow, K., \& Scott, P. (2012). Determinants of audit committees' activity: evidence from the UK. Social Responsibility Journal, 8(4), 471-483. https://doi.org/10.1108/17471111211272066

Aggarwal, R., \& Ghosh, A. (2015). Director's remuneration and correlation on firm's performance: A study from the Indian corporate. International Journal of Law and Management, 57(5), 373-399. 
https://doi.org/10.1108/IJLMA-08-2011-0006

Agyei-Mensah, B. K. (2016). Internal control information disclosure and corporate governance: Evidence from an emerging market. Corporate Governance, 16(1), 79-95. https://doi.org/10.1108/CG-10-2015-0136

Alabdullah, T. T. Y. (2016). Are Board Size And Ownership Structure Beneficial In Emerging Markets' Firms? Evidence From Jordan. International Journal of Management \& Information Systems, 20(3), 87-94. https://doi.org/10.19030/ijmis.v20i3.9752

Alipour, M. (2013). An investigation of the association between ownership structure and corporate performance: Empirical evidence from Tehran Stock Exchange (TSE). Management Research Review, 36(11), 1137-1166. https://doi.org/10.1108/MRR-08-2012-0188

Al-Najjar, B., \& Abed, S. (2014). The association between disclosure of forward-looking information and corporate governance mechanisms: Evidence from the UK before the financial crisis period. Managerial Auditing Journal, 29(7), 578-595. https://doi.org/10.1108/MAJ-01-2014-0986

Al-Saidi, M., \& Al-Shammari, B. (2015). Ownership concentration, ownership composition and the performance of the Kuwaiti listed non-financial firms. International Journal of Commerce and Management, 25(1), 108-132. https://doi.org/10.1108/IJCOMA-07-2013-0065

Aman, H., \& Nguyen, P. (2012). The size and composition of corporate boards in Japan. Asian Business \& Management, 11(4), 425-444. https://doi.org/10.1057/abm.2012.15

Appiah, K. O., \& Chizema, A. (2015). Remuneration committee and corporate failure. Corporate Governance, 15(5), 623-640. https://doi.org/10.1108/CG-11-2014-0129

Atiyet, B. A. (2012). The impact of financing decision on the shareholder value creation. Journal of Business Studies Quarterly, 4(1), 44-63.

Aymen, B. M. M. (2014). Impact of Ownership Structure on Financial Performance of Banks: Case of Tunisia. Journal of Applied Finance and Banking, 4(2), 163-182.

Baber, W. R., Liang, L., \& Zhu, Z. (2012). Associations between internal and external corporate governance characteristics:Implications for investigating financial accounting restatements. Accounting Horizons, 26(2), 219-237. https://doi.org/10.2308/acch-10267

Barros,C. P., Boubaker, S., \& Hamrouni, A. (2013). Corporate governance and voluntary disclosure in France. Journal of Applied Business Research (JABR), 29(2), 561-578. https://doi.org/10.19030/jabr.v29i2.7657

Ben, P. J. (2014). Corporate Governance Index and firm performance. Journal of Contemporary Research in Management, 9(3), 33-44.

Berezinets, I., Ilina, Y., \& Alekseeva, L. (2014). Dividends on Common and Preferred Shares: the Relationship with the Ownership Concentration in Russian Public Companies. Journal of economic and social development, 1(2), 48-59.

Bhatt, R. R., \& Bhattacharya, S. (2015). Board structure and firm performance in Indian IT firms. Journal of Advances in Management Research, 12(3), 232-248. https://doi.org/10.1108/JAMR-07-2014-0042

Bozec, R., \& Dia, M. (2015). Governance practices and firm performance: Does shareholders' proximity to management matter? International Journal of Disclosure and Governance, 12(3), 185-209. https://doi.org/10.1057/jdg.2014.3

Braje, I. N., \& Subic, R. (2016). Corporate Governance in banks : Using executive remuneration to manage risks. in an enterprise Odyssey. International Conference Proceedings.University of Zagreb, Faculty of Economics and Business.

Brennan, N.M. et Kirwan, C.E. (2015). Audit committees: practices, practitioners and praxis of governance. Accounting, Auditing \& Accountability Journal, 28(4), 466-493. https://doi.org/10.1108/AAAJ-01-2015-1925

Brunzell, T., \& Peltomäki, J. (2015). Ownership as a determinant of chairperson activity: A study of Nordic listed companies. Qualitative Research in Financial Markets, 7(4), 412-428. https://doi.org/10.1108/QRFM-09-2014-0029

Busta, I., Sinani, E., \& Thomsen, S. (2014). Ownership concentration and market value of European banks. Journal of Management \& Governance, 18(1), 159-183. https://doi.org/10.1007/s10997-012-9223-8 
Chahine, S., \& Zeidan, M. J. (2014). Corporate governance and market performance of parent firms following equity carve-out announcements. Journal of Management \& Governance, 18(2), 471-503. https://doi.org/10.1007/s10997-012-9245-2

Chakroun, R. (2013). Family Control, Board of Directors' Independence and Extent of Voluntary Disclosure in the Annual Reports: Case of Tunisian Companies. Journal of Business Studies Quarterly, 5(1), 22-42.

Chalermchatvichien, P., Jumreornvong, S., Jiraporn, P., \& Singh, M. (2014). The effect of bank ownership concentration on capital adequacy, liquidity, and capital stability. Journal of Financial Services Research, 45(2), 219-240. https://doi.org/10.1007/s10693-013-0160-8

Cheffou,A.I.(2014). Composition du conseil d'administration et rémunérations incitatives des dirigeants. Management \& Avenir, (5), 17-35. https://doi.org/10.3917/mav.071.0017

Chen, V. Z., Li, J., Shapiro, D. M., \& Zhang, X. (2014). Ownership structure and innovation: An emerging market perspective. Asia Pacific Journal of Management, 31(1), 1-24. https://doi.org/10.1007/s10490-013-9357-5

Dellaportas, S., Leung, P., Cooper, B.J., Lary, A.M. et Taylor, D.W. (2012). Governance characteristics and role effectiveness of audit committees. Managerial Auditing Journal, 27(4), 336-354. https://doi.org/10.1108/maj.2012.05127daa.001

Deudon, J. C., Marques, A. C., \& Sarens, G. (2015). Ownership concentration of three large Belgian banks during the crisis. Corporate Governance, 15(5), 663-677. https://doi.org/10.1108/CG-09-2014-0104

Eberhart, R. (2012). Corporate governance systems and firm value: empirical evidence from Japan's natural experiment. Journal of Asia Business Studies, 6(2), 176-196. https://doi.org/10.1108/15587891211254399

Ehsan, S., \& Javid, A. Y. (2015). Ownership Structure and Bank Performance: A Case of Banking Industry in Pakistan. Journal of Business \& Economics, 7(1), 1-27.

Fernandez, P. (2001). A Definition of Shareholder Value Creation, University of Navarra-IESE Business School. Social Science Research Network, Working Paper Series, 1-10.

Fülöp, M. T. (2013). Audit function role in achieving an efficient corporate governance-conceptual model proposal. Studia Universitatis" Vasile Goldis" Arad. Seria stiinte economice., 23(4), 87-97.

Garriga, E. (2014). Beyond stakeholder utility function: Stakeholder capability in the value creation process. Journal of Business Ethics, 120(4), 489-507. https://doi.org/10.1007/s10551-013-2001-y

Ghasemi, M., \& Ab Razak, N. H. (2016). Does the Size of Board of Directors and Executives affect Firm Performance in Malaysian Listed Firms? International Journal of Economics and Financial Issues, 6(6S),1-5.

Giugni Vidal, N., Berman, S., \& Van Buren, H. (2015). Stakeholder theory and value creation models in Brazilian firms. Revista Brasileira de Gestão de Negócios, 17(55),911-931. https://doi.org/10.7819/rbgn.v17i55.2070

Godard, L. (2002). La taille du conseil d'administration: déterminants et impact sur la performance. Revue Sciences de gestion, 33(2002), 125-148.

Goh, C. F., \& Rasli, A. (2014). CEO duality, board independence, corporate governance and firm performance in family firms: Evidence from the manufacturing industry in Malaysia. Asian Business \& Management, 13(4), 333-357. https://doi.org/10.1057/abm.2014.4

Gupta, R. K. (2013). Effects of Corporate Governance on Foreign Direct Investment. International Journal of Management", MIT College of Management, 1(1), 46-51.

Hashim, M. H., Nawawi, A., \& Salin, A. S. A. P. (2014). Determinants of strategic information disclosure-Malaysian evidence. International Journal of Business and Society, 15(3), 547-572.

Hall, J. H. (2012). Drivers creating shareholder value in South African manufacturing firms. Journal of Applied Business Research, 28(5), 1035-1048. https://doi.org/10.19030/jabr.v28i5.7243

Hall, T. W., \& Jörgensen, F. (2012). Ownership and performance in Europe.

Hanafi, M. M., Santi, F., \& Muazaroh. (2013). The impact of ownership concentration, commissioners on bank risk and profitability: evidence from Indonesia. Eurasian Economic Review, 3(2), 183-202. https://doi.org/10.14208/eer.2013.03.02.005

Hla, D. T., \& bin Md Isa, A. H. (2015). Globalisation of financial reporting standard of listed companies in asean two: Malaysia and Singapore. International Journal of Business and Society, 16(1), 95-106. 
Hoque, M.Z., Islam, M.R., Azam, M.N. (2013). Board committee meetings and firm financial performance: An investigation of Australian companies. International Review of Finance, 13(4), 503-528. https://doi.org/10.1111/irfi.12009

Honu, M. V., \& Gajevszky, A. (2014). The quality of financial reporting and corporate governance: evidence from romanian's aeronautic industry. Economic and Social Development: Book of Proceedings.

Ika, S.R. \& Ghazali, N.A.M. (2012). Audit committee effectiveness and timeliness of reporting: Indonesian evidence. Managerial Auditing Journal, 27(4), 403-424. https://doi.org/10.1108/02686901211217996

Inam, H., \& Mukhtar, A. (2014). Corporate governance and its impact on performance of banking sector in Pakistan. International Journal of Academic Research in Applied Science, 3(2), 26-36.

Ismail, T. H., \& El-Shaib, N. M. (2012). Impact of market and organizational determinants on voluntary disclosure in Egyptian companies. Meditari Accountancy Research, 20(2), 113-133. https://doi.org/10.1108/10222521211277825

Jaafar, S. B., \& James, K. (2013). Determinant of Director Remuneration in Malaysia Public Listed Companies. International Journal of Trade, Economics and Finance, 4(6), 353-367. https://doi.org/10.7763/IJTEF.2013.V4.316

Kara, E., Erdur, D. A., \& Karabiyik, L. (2015). Effects Of Corporate Governance Level On The Financial Performance Of Companies: A Research On BIST Corporate Governance Index (XKURY)/Kurumsal Yönetim Düzeyinin Isletmelerin Finansal Performansi Üzerindeki Etkisi: Borsa Istanbul Kurumsal Yönetim Endeksi (XKURY) Üzerine Bir Arastirma. Ege Akademik Bakis, 15(2), 265-274. https://doi.org/10.21121/eab.2015217991

Kao, T. H. W. H. S. (2014). The effect of IFRS, information asymmetry and corporate governance on the quality of accounting information. Asian Economic and Financial Review, 4(2), 226-256.

Khénissi, M. G. (2014). Le rôle des mécanismes de gouvernance dans la détermination de la rémunération des dirigeants: une analyse des sociétés cotées au SBF 120. Vie \& sciences de l'entreprise, (2), 29-54. https://doi.org/10.3917/vse.198.0029

Kibiya, M.U., Che-Ahmad, A. et Amran, N.A. (2016). Audit Committee Independence, Financial Expertise, Share Ownership and Financial Reporting Quality: Further Evidence from Nigeria. International Journal of Economics and Financial Issues, 6(7S), 125-131.

Kumar, N., \& Singh, J. P. (2013). Effect of board size and promoter ownership on firm value: some empirical findings from India. Corporate Governance: The international journal of business in society, 13(1), 88-98. https://doi.org/10.1108/14720701311302431

Lattemann, C. (2014). On the convergence of corporate governance practices in emerging markets. International Journal of Emerging Markets, 9(2), 316-332. https://doi.org/10.1108/IJoEM-06-2013-0093

Lee, S. P., \& Isa, M. (2015). Directors' remuneration, governance and performance: the case of Malaysian banks. Managerial Finance, 41(1), 26-44. https://doi.org/10.1108/MF-08-2013-0222

Lee,Y.,\&Lee,S.(2014). Interaction effects between ownership concentration and leverage on firm performance. Management Review: An International Journal, 9(1), 70-81.

Leong, K.S., Wang, J., Suwardy, T. et Kusnadi, Y. (2015). Audit Committees and Financial Reporting Quality in Singapore. Journal of Business Ethics, 139, 197-214.

Lin, T., Hutchinson, M. et Percy, M. (2015). Earnings management and the role of the audit committee: an investigation of the influence of cross-listing and government officials on the audit committee. Journal of Management \& Governance, 19(1), 197-227. https://doi.org/10.1007/s10997-013-9284-3

Li, W. A., \& Xu, J. (2014). Board independence, CEO succession and the scope of strategic change: Empirical research on the effectiveness of independent directors. Nankai Business Review International, 5(3), 309-325. https://doi.org/10.1108/NBRI-05-2014-0023

Liu, W., Yang, H., \& Zhang, G. (2012). Does family business excel in firm performance? An institution-based view. Asia Pacific Journal of Management, 29(4), 965-987. https://doi.org/10.1007/s10490-010-9216-6

Lin, C. P. (2012). IPO Underpricing, CEO duality, and Board Size: Factors that Affect Board Chair Change. Journal of Global Business Management, 8(2), 66-72.

Lynch, L. J., \& Williams, S. P. (2012). Does equity compensation compromise audit committee independence? 
Evidence from earnings management. Journal of Managerial Issues, 24(3), 293-320.

Malik, M., Wan, D., Ahmad, M. I., Naseem, M. A., \& Rehman, R. U. (2014). Role Of Board Size In Corporate Governance And Firm Performance Applying Pareto Approach, Is It Cultural Phenomena?. Journal of Applied Business Research, 30(5), 1395-1406. https://doi.org/10.19030/jabr.v30i5.8795

Martinov-Bennie, N., Soh, D.S.B. et Tweedie, D. (2015). An investigation into the roles, characteristics, expectations and evaluation practices of audit committees. Managerial Auditing Journal, 30(8/9), 727-755. https://doi.org/10.1108/MAJ-05-2015-1186

Man, C. K., \& Wong, B. (2013). Corporate governance and earnings management: A survey. Journal of Applied Business Research, 29(2), 391-418. https://doi.org/10.19030/jabr.v29i2.7646

Merino, E., Manzaneque, M., \& Priego, A. M. (2013). "Board independence" and compensation structure of directors. Copernican Journal of Finance and Accounting, 2(2), 125-131. https://doi.org/10.12775/CJFA.2013.020

Mirza, S. A., \& Javed, A. (2013). Determinants of financial performance of a firm: case of Pakistani Stock Market. Journal of economics and International Finance, 5(2), 43-52. https://doi.org/10.5897/JEIF12.043

Mohd-Sulaiman, A. N. (2013). Financial reporting failures, board's competency and effectiveness. International Journal of Disclosure and Governance, 10(2), 155-174. https://doi.org/10.1057/jdg.2013.5

Müller, V. O., Ienciu, I. A., Bonaci, C. G., \& Filip, C. I. (2014). Board Characteristics Best Practices and Financial Performance. Evidence from the European Capital Market. Amfiteatru Economic, 16(36), 672-683.

Nelson, S.P. et Devi, S. (2013). Audit committee experts and earnings quality. Corporate Governance. The international journal of business in society, 13(4), 335-351. https://doi.org/10.1108/CG-02-2011-0009

Nuhoglu, N. I., \& Erdogan, S. (2017). The Rise of" Independent Board Members" in TURKEY. Muhasebe ve Finansman Dergisi, (73), 249-271. https://doi.org/10.25095/mufad.396755

Pandya,B. (2016). Measurement of Shareholder Value Creation In India: A Research Design And Methodology. Sankalpa. Journal of Management \&Research, 6(1), 16-21.

Pucheta-Martínez, M. C., \& Narro-Forés, C. (2014). The compensation committee and the remuneration of the directors. Academia Revista Latinoamericana de Administración, 27(1), 46-74. https://doi.org/10.1108/ARLA-10-2013-0149

Rahman, H. U., Ibrahim, M. Y., \& Ahmad, A. C. (2015). How MCCG 2012 Impacted Board Independence and Firm Performance In Malaysia: A Proposed Analysis. Global Business and Management Research, 7(1), 21-31.

Rashid, A. (2013). CEO duality and agency cost: evidence from Bangladesh. Journal of Management \& Governance, 17(4), 989-1008. https://doi.org/10.1007/s10997-012-9213-x

Rodriguez-Fernandez, M., Fernandez-Alonso, S., \& Rodriguez-Rodriguez, J. (2014). Board characteristics and firm performance in Spain. Corporate Governance, 14(4), 485-503. https://doi.org/10.1108/CG-01-2013-0013

Sarpal, S., \& Singh, F. (2013). Board size and Corporate Performance: An Empirical Investigation. International Journal of Business Ethics in developing economies, 2(1), 1-34.

Siahaan, F. O. (2013). The Effect of Good Corporate Governance Mechanism, Leverage, and Finn Size on Finn Value. GSTF Business Review (GBR), 2(4), 137-142.

Shukla, H., \& Limbasiya, N. (2015). Board Effectiveness: An Evaluation based on Corporate Governance Score. International Journal of Business Ethics in Developing Economies, 4(1), 41-49. https://doi.org/10.21863/ijbede/2015.4.1.006

Singh, P. K. (2014). Shareholder Value Creation Through Unique Intangibles: Evidence From Selected Firm Listed in Bombay Stock Exchange. Journal of Contemporary Research in Management, 9(4), 1-14.

Singh, P. K., \& Anand, R. (2013). Shareholders' Value Creation and Market Capitalization-A Case Study of Automobile Industry in India. Journal of Contemporary Research in Management, 8(3), 1-14.

Sun, F., Wei, X. et Xu, Y. (2012). Audit committee characteristics and loss reserve error. Managerial Auditing Journal, 27(4), 355-377. https://doi.org/10.1108/02686901211217978

Sun, J., Lan, G. et Liu, G. (2014). Independent audit committee characteristics and real earnings management. Managerial Auditing Journal, 29(2), 153-172. https://doi.org/10.1108/MAJ-05-2013-0865 
Syriopoulos, T., \& Tsatsaronis, M. (2012). Corporate governance mechanisms and financial performance: CEO duality in shipping firms. Eurasian Business Review, 2(1), 1-30.

Sun, J., Lan, G., \& Ma, Z. (2014). Investment opportunity set, board independence, and firm performance: The impact of the Sarbanes-Oxley Act. Managerial Finance, 40(5), 454-468. https://doi.org/10.1108/MF-05-2013-0123

Vintila, G., \& Gherghina, S. C. (2013). Board of directors independence and firm value: empirical evidence based on the bucharest stock exchange listed companies. International Journal of Economics and Financial Issues, 3(4), 885-900.

Viviers, S. (2015). Executive remuneration in South Africa: key issues highlighted by shareholder activists. African Journal of Business Ethics, 9(1), 1-28. https://doi.org/10.15249/9-1-112

Wang, Y. C., Tsai, J. J., \& Lin, H. W. W. (2013). The influence of board structure on firm performance. Journal of Global Business Management, 9(2), 1-14.

Wincent,J., Anokhin, S., \& Örtqvist, D. (2010). Does network board capital matter? A study of innovative performance in strategic SME networks. Journal of Business Research, 63(3), 265-275. https://doi.org/10.1016/j.jbusres.2009.03.012

$\mathrm{Wu}, \mathrm{X} ., \& \mathrm{Li}, \mathrm{H}$. (2015). Board independence and the quality of board monitoring: evidence from China. International Journal of Managerial Finance, 11(3), 308-328. https://doi.org/10.1108/IJMF-07-2014-0101

Yin, F., Gao, S., Li, W., \& Lv, H. (2012). Determinants of audit committee meeting frequency: evidence from Chinese listed companies. Managerial Auditing Journal, 27(4), 425-444. https://doi.org/10.1108/02686901211218003 